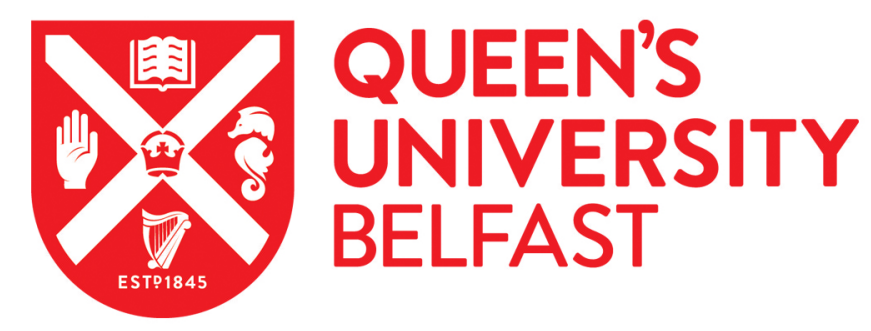

\title{
Urban restructuring, social economics and violence after conflict
}

Murtagh, B., Grounds, A., Boland, P., \& Fox-Rogers, L. (2019). Urban restructuring, social economics and violence after conflict. Third World Thematics: A TWQ Journal. https://doi.org/10.1080/23802014.2019.1674184

Published in:

Third World Thematics: A TWQ Journal

Document Version:

Peer reviewed version

Queen's University Belfast - Research Portal:

Link to publication record in Queen's University Belfast Research Portal

Publisher rights

Copyright 2019 Taylor and Francis. This work is made available online in accordance with the publisher's policies. Please refer to any applicable terms of use of the publisher.

\section{General rights}

Copyright for the publications made accessible via the Queen's University Belfast Research Portal is retained by the author(s) and / or other copyright owners and it is a condition of accessing these publications that users recognise and abide by the legal requirements associated with these rights.

Take down policy

The Research Portal is Queen's institutional repository that provides access to Queen's research output. Every effort has been made to ensure that content in the Research Portal does not infringe any person's rights, or applicable UK laws. If you discover content in the Research Portal that you believe breaches copyright or violates any law, please contact openaccess@qub.ac.uk. 


\section{Urban restructuring, social economics and violence after conflict}

Forthcoming in Third World Thematics

Social Edition The spatiality of violence in postwar cities.

\section{Guest editors}

Professor Kristine Höglund, Department of Peace and Conflict Research, Uppsala University, Sweden; Dr. Emma Elfversson, researcher, Department of Peace and Conflict Research, Uppsala University, Sweden; Dr. Ivan Gusic, researcher, Department of Political Science, Lund University, Sweden.

\section{Authors}

Brendan Murtagh (b.murtagh@qub.ac.uk), Andrew Grounds (a.grounds@qub.ac.uk), Philip Boland (p.boland@qub.ac.uk) and Linda Fox-Rogers (1.fox-rogers@qub.ac.uk)

Authors affiliation: School of Natural and Built Environment, Queen's University Belfast, David Keir Building, Stranmillis Road, Belfast, BT9 5AG, UK.

\section{ORCID}

Brendan Murtagh 0000-0002-9417-6052

Andrew Grounds 0000-0002-8432-068X

Philip Boland 0000-0003-1011-2447

Linda Fox-Rogers 0000-0002-6131-4789 


\begin{abstract}
This paper argues that the spatiality of violence needs to pay attention to the production of space as well as the nature of conflict in post-war conditions. Regimes of violence and how they live on in peace, emphasises the need to see how they are assembled in relation to economic, state and social processes implicated in placemaking. Coercion, control and surveillance are all part of the necessary assemblage of ethnic conflict, and in its aftermath, different forms of violence (or simply the threat of violence) reproduce identarian conflict and simultaneously exploit its reproduction. Liberal and increasingly neoliberal forms of peace fail to connect with the people and places most damaged by conflict and the relationship between poverty, sectarianism and place intensify the conditions for enduring forms of paramilitarism and ultimately violence. The paper draws on Belfast, Northern Ireland to argue that tackling the distinct economic conditions of the most marginal places is a critical but undervalued dimension of violence after peace. The analysis concludes by evaluating the potential of the Social and Solidarity Economy in transitional processes in which the relationship between violence, place and poverty are constitutive of embedded forms of materialist peacebuilding.
\end{abstract}

Key words: Paramilitarism; Northern Ireland; peacebuilding; social economics; violence, DDR. 


\section{Introduction}

The spatial distribution of violence after war reflects a complex interaction of unresolved hurts, the survival and rehabilitation of military structures and new political, economic and cultural forces unleashed by peace-makingi. The definition of violence in this paper draws on Steenkamp and 'the use of force that is interpersonal: it has an object and a subject and is a sensory experience. ${ }^{\text {ii }}$ Structural violence, including economic exploitation, social exclusion and poverty, of course, shape the trajectory of peace in post-war cities. However, to conflate these as 'violence' obscures the separate processes of exclusion that, it is argued here, need to be understood on their own terms. The maintenance of paramilitary structures, the state and the economy all assemble and reproduce space in a complex relational process. But they are also distinct realities that cannot be reduced to violence as a singular analytical and/or empirical category. Returning to Steenkamp, the paper thus makes a distinction between economic exclusion and 'direct violence ... against a person (or persons), violence could also be directed against an object with the aim to cause damage. ${ }^{\text {iii }}$ In this analysis, space is relational, but the paper argues that understanding the spatiality of violence needs to move beyond simplistic distinctions between material and perceptual readings of the city. How space is produced by multiple, competing and overlapping systems focuses attention on the mechanics of place making after war. Here, we draw on a critical urban literature that explores how space is assembled, disassembled and reassembled, especially in post-conflict conditions.

In his work on urban assemblages, McFarlane argues that space is not abstract but can be understood by tracing the institutions, resources, policies, laws and the tactics of actors with a stake in the production, management and use of land ${ }^{\text {iv }}$. In post-war cities these involve a more complex interplay of ethnic as well as material processes that constitute the politics of urban change. Here, Yiftachel and Ghanem are also concerned with the production of space and they 
see cities formed by the assemblage of governance (how the state works); capital (economic interests); and ethnography (the survival of ethnic forces) ${ }^{\mathrm{v}}$. These assemblages are incomplete, overlapping and unique but focus attention on both material space and ethnic interests in a more complex process that rolls-out unevenly in the transition from war to peace.

First, the paper examines the nature of conflict after peace and in particular, the importance of competing assemblages that are shaped by but also shape different, even contradictory trajectories of violence and peace in the same post-war city. Alternative networks of paramilitaries; state governance; and economics assemble space differently, for different purposes (petty power, public order or profit) and with different effects on the intensification of violence or (effectively) ending it. It is these structures that need to be unpacked in order to understand the reproductive potential of violence, but also how it can be encountered in conditions of peace. The paper next evaluates strands of violence in Northern Ireland in the context of the demobilization, criminalisation and reintegration of former paramilitary prisoners and ex-combatants. It shows that these are correlated with patterns of poverty and how they are spatialized in the most divided and damaged communities. Dissident republicans who refused to compromise unification and loyalists who saw criminal potential in the ceasefire are evidence of distinct means-ends complexities in the use of violence. The analysis then outlines a case study describing the assembly of an alternative Social and Solidarity Economy (SSE) in north Belfast which aims to address the multiple layers of conflict through a network of social enterprises, services and assets. The SSE is itself an interdependent collection of community businesses, intermediaries, social entrepreneurs and community finance providers that engage in economic activity (trading in goods and services) but for exclusively ethical purposes $^{\mathrm{vi}}$. The paper concludes by arguing that the business of peace-making in places left behind after conflict is about assembling the structures, economic opportunities and pathways 
that give communities a meaningful stake in social and economic mobility across the poorest places.

\section{Space and the spatiality of violence}

The spatial turn in peacebuilding has produced important empirical and conceptual understandings of the relationship between place, human agency and violence ${ }^{\mathrm{vii}}$. Björkdahl and Kappler define spatiality as 'the particular configuration of social relations, built forms, and human activity in a particular space and its geographic sphere of influence. It arises from the social production of space as a distinct material and symbolic context or habitat for human life. The notion of spatiality helps us comprehend the moral, political, economic and social contours of space. ${ }^{\text {viii }}$ This builds on a Lefebvreian understanding of the social production of place and how it is made, used and represented in different ways. In his work on Mitrovica (Kosovo), Gusic also emphasises the relational nature of space and also draws on Lefebvre's triad of conceived (as created by planners and urban managers); perceived (of everyday social life); and lived (of the imagination) space ${ }^{\mathrm{ix}}$. This is useful framing but takes the understanding of space so far and in particular, emphasises the subjectivities of place rather than modes of production, tends to devalue global externalities and related temporal processes and often provides comparatively little insight into what can be done in peacebuilding, as an explicit normative act.

The focus on relational place is presented as a new turn, worthy of its own self-contained categorical analysis, but is there any serious scholarship in urban or peace studies that argues for a strict Euclidean concept of space? In his seminal work on Lefebvre, Unwin argues that the idea is so accepted in urban research that it barely 'needs justification. ${ }^{\mathrm{x}}$ This then tends to treat categories descriptively rather than analytically or normatively. For example, there are 
social patterns that show how space is perceived as dangerous and behaviours of avoidance do reproduce segregation. But, it does not show how such material urban forms are produced, what agents are involved and what methods they use to reinforce separateness. This places a descriptive emphasis on the consumption of space rather than on explicit modes of production including, it is argued in this paper, inter alia, economic interests, the state and extant paramilitary groups ${ }^{\mathrm{xi}}$.

Moreover, such descriptions fail to explain the contradictions between real and imagined space and crucially how they are resolved (or not) over time. This privileges a 'new kind of spatial fetish' that disconnects reproduction from temporal processes. ${ }^{\text {xii }}$ Space has been significantly restructured in response to neoliberal urbanism, globalisation and technology. Castells assertion of a more networked world characterised by 'time-space compression' has profound effects on violent cities and in particular, the peacebuilding strategies of international donors ${ }^{\mathrm{xiii}}$. Liberal interventions characterised by the restoration of markets, private property rights and democracy have given way to more aggressive neoliberal strategies that promote deregulation, privatisation and access to capital ${ }^{\mathrm{xiv}}$. In short, space in post-war cities have been profoundly affected by temporal scales of influence (including the shifting priorities of the World Bank, International Monetary Fund and the European Union) in which the local might have little or no control. Treating space as an 'end product' (in that it is produced) takes away from the fundamental politics, ideologies, sectarianism and here we argue, economic processes, that ultimately create uneven development. How places are interpreted by residents, represented by policy makers or exist in material terms, detracts from the way in which the structural drivers of exclusion create resource competition, human misery and violence ${ }^{\mathrm{xv}}$. How then, space provides a framework for meaningful political action is an area where community relations practice, certainly in Northern Ireland, is comparatively silent ${ }^{\mathrm{xvi}}$. In his later work, Lefebvre 
addressed this limitation in his critique of 'territorial autogestion' in which 'participation and appropriation (legally distinct from the right to property), are implied in the right to the city. ${ }^{\text {xvii }}$

Here, the emphasis shifts to how space can be reclaimed through local ownership, community appropriation and self-management. The organisational strategies, structures and practices constitutive of autogestion also need to be assembled as a process of place making after war. In her work on post-accord conflict, Steenkamp shows how 'networks of violence' can prove remarkably resilient in marginal communities with less investment in peace processes ${ }^{\mathrm{xviii}}$. In such sites, the fundamental structural problems that cause resentment, alienation and ultimately violence remain largely unaltered, leaving instabilities easily exploited by ethnic entrepreneurs and (re-formed) criminal networks. Steenkamp writes that:

Former social relationships of power and dependency often survive the transition to peace with relative ease; communities may see fewer economic dividends than expected and their political and social marginalisation remains high or increases ${ }^{\mathrm{xix}}$.

As with Yiftachel and Ghanem, Steenkamp makes the connection between ethnic and economic processes in understanding the spatial distribution of violence and how it is structured after war. How it is structured places attention on competing assemblages built around extant paramilitary structures, new forms of capital or alternatives that refuse the authority of either - a difficult and marginal space of resistance but one that clearly exists. Poverty can certainly amplify tribalism but equally, economic development (capital in Yiftachel and Ghanem's terms) can also create a new cosmopolitan landscape that significantly loosens the bonds of ethno-spatial politics. The state assembles the necessary zoning regulations, fiscal incentives, land-banks, marketing and governance regimes (development 
corporations, public-private partnerships and so on) that enable capital to extend its influence as a natural and logical solution in post-war cities ${ }^{\mathrm{xx}}$. But this leaves behind places and people not useful for the accumulation process and here the creative reassembly of extant (and often intact) paramilitary structures re-exploits the alienation that characterised times of violence.

Yiftachel and Ghanem argue that contested cities can also be understood in relation to assemblages and underscore the need to evaluate the processes that explain different spatial outcomes $^{\mathrm{xxi}}$. As noted, they focus on the relationship between capital, governance and ethnicity and the interplay between them, especially in transitional post-conflict conditions. These processes are also acted out in constant tension in the city, producing differentiated spaces in which capital has pushed out sectarian elites in privileged investment sites; or where violence persists when capital cannot (or does not) assert its authority. Here, capital does not roll-out and roll-over the city effortlessly, as neoliberal critics argue, but is checked by embedded ethnic forces, territories and paramilitary structures ${ }^{\mathrm{xxii}}$. In short, ethnocratic and capital regimes are in constant competition - assembling and reassembling resources, actors and networks to justify the extension of their interests, in which the state may favour (or actively pursue) the maintenance of ethnic over market outcomes.

There is a danger that we essentialize space in contested cities and see it inexorably linked to a civilian clash between warring parties. Rather, as Latour argues, space is assembled by actors with (economic, ethnic or political) capital who deploy a range of strategies to pursue their interests and take advantage of networks, governance arenas and formal political structures to gain advantage over competitors ${ }^{\mathrm{xxiii}}$. These interests seek to legitimise their actions (via force, political alliances, rhetoric, legal and quasi-legal means and so on) and offer competing 
explanations and normative possibilities for the city as a cultural, economic and social resource. For McFarlane, urban assemblages involve human actors, institutions, policy scripts and material infrastructures (land, property development, transport and so on) that can be variously reassembled in alliances, formal networks, tactics and sites of disruption ${ }^{\text {xxiv }}$. They are built around overlapping power relationships, resource allocation (and ownership) processes, technologies and the use of information as knowledge production ${ }^{\mathrm{xxv}}$. How various assemblages compete to reproduce different forms of ethnic and economic space, will be considered next in the particular context of Northern Ireland.

\section{Northern Ireland: conflict and peace}

The political complexities of Northern Ireland are bound up in the agreement that ended the Irish War of Independence (1918-21). The Anglo-Irish Treaty in 1921 divided Ireland between the 26 independent counties that later formed the Republic of Ireland and six counties in Northern Ireland that remained part of the United Kingdom, with its own regional government at Stormont. Northern Ireland was defined and designed to in-build a Protestant majority, who mainly want to maintain the union with Great Britain. The Catholic minority largely retain an aspiration for reunification and until the 1998 Good Friday Agreement (GFA), the Irish government laid sovereign claim to the island of Ireland, including the six northern counties $^{\mathrm{xxvi}}$.

The internal contradictions, discrimination and inefficiencies of the state (in housing, infrastructure and fair employment) were the focus of the civil rights movement throughout the 1960s and despite limited reforms, the region collapsed into intercommunal violence in 1969. The Provisional Irish Republican Army (PIRA) reconstituted, initially in defence of Catholic neighbourhoods, launched an aggressive guerrilla campaign for unification that effectively ended with the GFA. Loyalist paramilitaries, principally the Ulster Volunteer Force (UVF) and 
the Ulster Defence Association (UDA), scaled their own violent sectarian campaign aimed primarily at Catholic civilians ${ }^{\mathrm{xxvii}}$. Spatial segregation between Catholics and Protestants intensified, especially in inner-city, working-class neighbourhoods and the majority of the 3,400 deaths and 60,000 injuries during the Northern Ireland Troubles were concentrated in the most disadvantaged areas ${ }^{x x v i i}$. There are now 40 physical peace lines or interfaces separating Catholic and Protestant neighbourhoods in Belfast, although such terms relate to a more complex political spectrum within and between the two main communities. On the Catholic side, there is a distinction between constitutional nationalism and republicanism (the latter generally supportive of the armed struggle of the IRA); whilst on the Protestant side, more moderate political unionism can be distinguished from loyalism, again which has links to paramilitary organisations (including the UDA and UVF).

A number of critics argue that the problem with the Northern Ireland peace process was that it framed a consociationalist settlement, which reinforced sectarian elites but failed to impact on the everyday experiences of the most affected communities ${ }^{\mathrm{xxix}}$. The Agreement consisted of three strands dealing with: new political institutions within Northern Ireland; the relationship between Northern Ireland and the Republic of Ireland; and the relationship between the Republic of Ireland and the United Kingdom. A new power sharing Assembly and Executive was set up under strand one; and strand two established a North-South Ministerial Council, a Consultative Forum and executive bodies dealing with issues such as trade, tourism and EU funding. Strand three aimed to strengthen cooperation between the UK and the Republic of Ireland in areas that were not devolved to the Northern Ireland Assembly. The Agreement also set out a process of paramilitary decommissioning and the reform of policing, leading to the creation of the Police Service of Northern Ireland (PSNI), eventually placed under the control of the Executive. 
Since 1998, politics in Northern Ireland gradually polarised through successive Assembly elections, collapses of the institutions and as details of the Agreement (such as language rights and decommissioning) were or were not implemented ${ }^{\mathrm{xxx}}$. The more moderate Ulster Unionist Party and Social Democratic and Labour Party who effectively negotiated the settlement, were squeezed out by the more fundamentalist Democratic Unionist Party (DUP) and Sinn Féin within unionism and nationalism respectively. The Assembly has been suspended since February 2017 due to the financial mismanagement of a renewable energy scheme led by the DUP and a failure to progress legislation on the Irish language, gender rights and marriage equality $^{\mathrm{xxxi}}$. The political divide has sharpened since a 2016 UK referendum resulted in a decision to leave the European Union ('Brexit'), not least because it is likely to harden the border, reduce the sense of an all-island citizenry (especially for Catholics) and reinforce an enclosed unionist mentality in Northern Ireland ${ }^{\mathrm{xxxii}}$. This, in turn, has helped to resuscitate, albeit fringe republican movements, violence in mixed neighbourhoods and new forms of criminality among extant paramilitary groups, especially in Loyalist areas ${ }^{\mathrm{xxxiii}}$.

In such conditions, violence lives on, primarily related to exploitation via organised crime, human trafficking and the drugs trade ${ }^{\mathrm{xxxiv}}$. Greed explains a political economy of war in which opportunistic violence takes advantage of moments of destruction, anarchic transition and weak authority $^{\mathrm{xxxv}}$. Certainly, the level of racketeering, especially among loyalist paramilitaries, is supported by coercion and control to bolster exclusively criminal economic networks ${ }^{\mathrm{xxxvi}}$. In the search for legitimacy, old habits in community surveillance and control including punishment beatings, expulsions and assassinations are maintained and even extended. Paramilitaries on both sides have used maiming and expulsion to impose internal control and 
in the uncertain transition to a new policing service, these practices have endured and, in some areas, intensified ${ }^{\mathrm{xxxvii}}$.

The attempt to bring in the Irish and British governments as co-guarantors of the GFA and create a new architecture of north-south and east-west political structures, aimed to reposition the state as an even-handed arbiter of a distinctly local accommodation. But these arrangements have now been significantly ruptured by the UK Conservative government's Confidence and Supply Agreement with one side, the DUP, in 2017, the potential of a hard border and deteriorating Anglo-Irish relations ${ }^{\mathrm{xxxviii}}$. Moreover, the role of British security forces in civilian deaths (during the conflict) and evidence of significant collusion with loyalist paramilitaries, as well as a failure to pursue convictions for army killings, enables violence to live on in unresolved ways $^{\text {xxxix }}$. The idea that republicans faced the full weight of the judicial system while state violence escapes such scrutiny, persistently undermines the British government as an honest broker in the peace process ${ }^{\mathrm{xl}}$.

Moreover, the areas that were the poorest throughout the Northern Ireland conflict are still the poorest and poverty drops down the generations to further disconnect already segregated places from new opportunities in the growth economy ${ }^{x l i}$. The ceasefires in the mid-1990s brought with it, significant inward investment, knowledge-intensive industries and mobility in the housing and labour market reflected in the expansion of mixed, middle-class neighbourhoods, especially in the south of the city. Belfast has seen poverty and interfacing increase in the west and north at the same time as desegregation, investment and prosperity increased in the south and east. The ethnocratic city has not been displaced by the cosmopolitan imagery that postconflict Belfast likes to present but lives on in new peace lines dividing Catholic and Protestant communities, re-formed paramilitary groups and ultimately violence. 
Demobilisation and demilitarisation reduced the potential for violence but did not eradicate it as old paramilitary structures were put to new uses. The lack of an effective and agreed settlment provides space for such processes to gain traction, rehabilitate former combatants and maintain a form of local legitimacy. This political violence, in broad terms, is aimed at derailing peace in order to return to war by those unreconciled to any form of settlement. Dissident republican groups may be ideologically splintered and lack military capacity but remain a threat, especially when macro forces (Brexit, austerity, poverty and so on) reenergise their purpose $^{\text {xlii }}$.

Table 1 shows that sustained levels of violence persisted after the 1998 Agreement in terms of both shootings and paramilitary assaults. The average number of paramilitary incidents did decline after the ceasefires, but it is the intra-group patterns that are most significant. Loyalist shootings per annum hardly changed pre- (35) and post- (34) ceasefire, compared with a substantial decline from 49 to 29 per annum for republicans. Moreover, paramilitary assaults increased by $56 \%$ among loyalists, whilst republican attacks declined by $50 \%$ over the same period.

Table 1 Casualties as a result of paramilitary style attacks in Northern Ireland 19732018 $^{\text {xliii }}$

\begin{tabular}{|l|c|c|c|c|c|c|c|}
\hline Type & \multicolumn{3}{|c|}{ Paramilitary style shootings } & \multicolumn{3}{c|}{ Paramilitary style assaults* } & $\begin{array}{c}\text { Casualties } \\
\text { (Shootings } \\
\text { and } \\
\text { Assaults) }\end{array}$ \\
\hline Group & Total & Loyalist & Republican & Total & Loyalist & Republican & \\
\hline No. 1973-1998 & 2169 & 902 & 1267 & 1428 & 617 & 811 & 2683 \\
\hline Mean 1973-1998 & 83 & 35 & 49 & 84 & 36 & 48 & 158 \\
\hline No. 1998-2018 & 1265 & 688 & 577 & 1601 & 1124 & 477 & 2866 \\
\hline Mean 1998-2018 & 63 & 34 & 29 & 80 & 56 & 24 & 143 \\
\hline
\end{tabular}




\section{Case study: violence and its spatial reassembly}

Removing weaponry and normalising policing are critical but the process has been uneven and incomplete, which affects both the pace and spatial distribution of peace after war. Dwyer points out that the Disarmament, Demobilisation and Reintegration (DDR) process in Northern Ireland involved a unique combination of top-down, state-led strategies and community-based participatory processes ${ }^{\mathrm{xliv}}$. The GFA set out a programme of demilitarisation by both state and non-state actors, including the removal of the British army presence, the reform of policing and eventually the decommissioning of paramilitary weapons. However, Shirlow argues that a combination of hard and soft laws continues to exclude former (paramilitary) prisoners, rendering DDR incomplete and allowed paramilitaries to exist in a transitional state where their structures often offered the only source of support and income ${ }^{x l v}$. Hard laws, especially vetting and security checks work as 'exclusionary code' on participation (in employment) but the soft space (structures to change employment guidance through a Review Panel) has little effect on their citizenship rights ${ }^{\text {xlvi }}$. For Shirlow, the demobilisation and disarmament phases of the peace process were clear but there was little legislative, resource or even public weight behind the reintegration phase. The Review Panel was established to produce guidance and advice to encourage employers to implement vetting procedures flexibly, but legislative restrictions on the recruitment of people with convictions remained largely in place ${ }^{\mathrm{xlvii}}$. The debate about former prisoners thus lurches between apologia and justification of the past, to shame and humiliation, so they exist in a nowhere space that is ultimately dangerous for their potential

roles as peace makers, spoilers or criminals. Shirlow shows that between 2005 and 2015 there was no improvement in the proportion of former paramilitary prisoners in paid employment; that those in receipt of welfare benefits increased from 57\% to $71 \%$; and that those who had 
not been successful with a job application as a result of their conviction rose from $53 \%$ to $74 \%$ xlviii

Nussio argues that ex-combatants gather mixed and contradictory perceptions of post-conflict opportunities and make judgements on how they impact on their personal and collective interests $^{\text {xlix }}$. These are not pre-determined, but their variability makes all peace processes unstable and responsive to extra local shocks in which violence remains a constant threat. We can identify three broad responses by ex-combatants in Northern Ireland, each one characterised by a distinct assemblage of institutional actors, set of practices, motives and relationships with place. In the first, both republican and loyalist paramilitaries dismantle their structures and aim to displace systems of violence with community development initiatives. In the second, some loyalist paramilitaries use their networks and weaponry to create criminal structures in which violence and exploitation re-establish their presence, reinforced via territorialised turf war. Third, republican paramilitaries, who rejected the GFA and refused the citizenry of the re-formed state, splintered both ideologically and organisationally. But they retain a loose assemblage of paramilitary networks, logistics and materials as evidenced by recent arms finds, bombings and shootings ${ }^{1}$.

In the first set of responses, McEvoy and Shirlow argue that the maintenance of paramilitary structures was critical to transitional processes and embedding peace across ex-combatants, former prisoners and within mainstream loyalist and republican communities ${ }^{\mathrm{li}}$. Indeed, Joyce and Lynch emphasise the performative aspect of ex-combatant contacts after violence. They show how former loyalist and republican paramilitaries engaged in a programme of work with

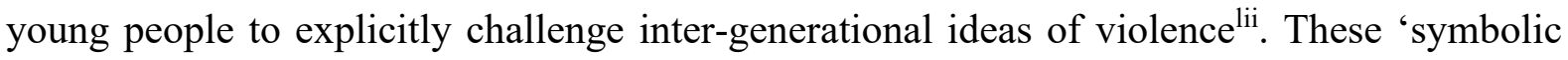
contacts' were designed to 'send a message' to young people about the long-term consequences 
of paramilitarism and criminality in particular ${ }^{\text {liii }}$. This goes beyond 'humanising the in-group' to deliver a range of community development interventions aimed at young people in particular $^{\text {liv }}$. McEvoy and Shirlow also show how former loyalist paramilitaries effectively policed out violence at some interface areas and because they had both authority and contacts with republicans, could enforce unscripted rules governing relations with the other. ${ }^{\text {lv }}$ For example, both loyalist and republican paramilitaries have been involved in community restorative justice initiatives as an alternative to punishment attacks. This has, they argue, reduced the legitimacy of paramilitaries but also strengthened community accountability and a number of schemes are now accredited and funded by the state, with a formal role in the criminal justice system.

Coulter and Shirlow also describe how loyalist paramilitaries evolved politically through a process of critical dialogue about their own relationship with the state ${ }^{\mathrm{vi}}$. The Progressive Unionist Party (PUP), formed as a left-leaning working-class movement linked to the UVF, explicitly distanced itself from the elite unionist class and even ideas of Britishness. The PUP argued that the Protestant working-class was as damaged as the Catholic poor and manipulated cynically via imperialist tropes, notions of fealty and (minor) rewards to secure their participation in a distinct Northern Ireland statecraft. The acknowledgement that sectarianism divided and weaponised the working-class against each other emerges as an important discourse within post-conflict loyalist narratives, but it failed to scale as a coherent political project. Criminality, insecurity about the future of the union and polarisation of both unionist and nationalist politics effectively squeezed out middle ground activism. The failure to develop a coherent political network within working-class unionism and across to nationalist areas renders a class-based assemblage for the city largely unrealised. 
Extant regimes of violence and their survival in post-conflict conditions, demonstrate the resilience and adaptive capacity of some assemblages over others. In the second set of responses, logics of violence persist in poverty, lack of alternatives and the momentum embedded in the practices and values of pre-peace conditions. For example, Loyalist command structures, motivation and discipline were less well organised than republicans, not least because they occupied an uncertain space with state security services whose primary purpose was also to uphold the union ${ }^{\text {lvii }}$. Indeed, as noted earlier, significant levels of involvement in (and directing) loyalist violence and related networks of informers, emphasise the extent of state penetration in both the UVF and UDA ${ }^{\text {lviii }}$. More recently, the PSNI described how young people are attracted into such networks but are then forced into more serious crimes. Punishment beatings and executions keep both the membership and the community in line, even if youth workers and church leaders periodically speak out to challenge their authority ${ }^{\text {lix }}$. Loyalist paramilitaries now operate significant drug networks involving international suppliers, extreme violence and the control of some working-class Protestant communities ${ }^{\mathrm{lx}}$.

In the third response, dissident republican restructuring is wedded to old ideologies that might operate at the political margins, but which can be rehabilitated by events such as Brexit and the opportunities they open. Hoey points out that the dissident movement is broad but splintered and connects a range of groups that maintain either an overt support for republican violence (such as the Continuity, Real and New IRA) or offers it qualified political support (such as the 32 County Sovereignty Movement [32CSM] or Republican Sinn Féin) ${ }^{1 \mathrm{lxi}}$. The failure by fringe groups to present a new political analysis within anti-establishment republicanism, left it in an increasingly marginal space, further threatened by non-militarist movements such as the socialist People Before Profit party who won two Assembly seats in inner-city Derry/Londonderry and west Belfast in 2016. 
However, the decline in dissident competence and military capacity is also affected by external political events set off by Brexit. The prospect of border infrastructure, customs processes and staff and in all likelihood, security forces, was what one dissident called 'a shot in the arm for republicans. Any sort of border checkpoint would be a provocation'xii . O'Brennan pointed out that the GFA accommodated nationalist and unionist identities, partly because of de-bordering processes in north-south relations, facilitated by European market integration ${ }^{\text {1xiii }}$. Equally, rebordering, which is the logical implication of Brexit and the subsequent hard-line adopted by the DUP, unnerved middle-class Catholics in particular. Residual violence can be given life when inequalities and uneven responses revitalise dissident republicans and related fears of a reasserted Unionist-British hegemonic mind-set.

\section{Counter-assemblages and places of conflict}

Björkdahl and Kappler make the point that all conflicts change, are restructured and in uncertain transitional processes, new explanations, alliances and possibilities arise. Places such as Belfast can no longer be understood as a post-colonial relic nor an ethnic-religious conflict shaped by identity competition ${ }^{\text {lxiv }}$. Most significant in this respect is a materialist conceptualisation of how the Northern Ireland conflict has moved into a phase where poverty, exclusion and alienation are strongly connected with the most divided places. But arguing for a materialist understanding of conflict faces considerable barriers, not least the paradigmatic hegemony of community relations and social distance models. Approaches premised on a civilian clash supports a distinct assemblage of NGOs, specialist mediation groups, think-tanks, peace entrepreneurs, universities and government sponsored programmes. Researchers reinforce the epistemological centrality of contact, premised on a reductive understanding of social distance and the evident need for more patient relationship building at the interpersonal 
and inter-group level. But identities and space have restructured, at least for the socially mobile, and more significant (gendered, age and sexual) identities cut across old sectarian enmities in significant economic and spatialised ways ${ }^{\mathrm{lxv}}$. This is not to suggest that understanding prejudice and engaging children and young people in contact programmes are not valuable, only that there needs to be a more systematic appreciation of the relationship between poverty, economic development and violence. A number of post-conflict societies have developed the SSE as a transitional process in order to displace deviant economies of violence and provide alternative structures in places were the case for peace is not that convincing, at least for some.

In Colombia, this process has drawn on social innovation methods and in particular, the development of agriculture (and diversified income streams), away from illegal crops and the paramilitary networks on which many farmers relied ${ }^{\mathrm{lxvi}}$. Red Prodepaz (Network of Peace and Development Programs) has integrated around 3,000 family holdings into the local economy, improved agricultural practices, strengthened supply chains and created more stable prices for the small farm economy. The World Bank concluded that 'in post-conflicts scenarios, one of the most important reasons to support social innovation is the contribution made by these policies and actions to addressing growing inequalities that in the long term could re-establish conflict dynamics. 'lxvii Khoury and Prasad also linked the intensification of violence in Palestine to a lack of economic opportunity but highlighted 'institutional voids' in helping the poorest communities to address exclusion and create realistic pathways out of ethnic conflict $^{\text {lxviii }}$. This included access to technical support, credit and effective market structures to supply basic goods and services to the poorest communities. The local might offer a frame for peacebuilding practice but an assemblage of institutions, laws and resources are needed to counter the structural violence that reproduce poverty and unequal power relations ${ }^{\text {lxix }}$. 
Indeed, Satgar showed that the co-operative movement in post-Apartheid South Africa largely failed because it was too rooted in unprofitable townships and lacked the capital, technical skills and markets to scale up as a sustainable sector ${ }^{1 \mathrm{xx}}$. The opposite happened in the Basque Country. Morgan argued that part of the reason for the decline in violence here was a renewed focus on the effects of deindustrialisation and social mobility through the extensive development of the cooperative sector ${ }^{1 x x i}$. Social enterprises are the backbone of the Basque economy in which material progress and inclusive economics has moved ahead of identity concerns and separatist politics. What is significant about these responses, is that they do not rely on a single spatial intervention but rather, build an infrastructure of laws, finance, skills, supply chains and firms that are necessary to compete with logics of violence and paramilitarism. Whether such infrastructure can be deliberately assembled as part of peace building is explored in the case study of the SSE in north Belfast.

North Belfast is the most divided area of the city, with $40 \%$ of interfaces and with one of the highest concentrations of deaths during the Troubles. It still suffers from inter- and intracommunity violence, paramilitaries on both sides are active and increasingly violent and it remains one of the poorest places in the $\mathrm{UK}^{1 \mathrm{xxii}}$. The Ethical Development Trust (EDT) is a partnership between Queen's University and two large social enterprises, the Ashton Community Trust (ACT) and LEDCOM who are involved in urban regeneration and community economic development. The Trust invested $£ 1.5 \mathrm{~m}$ to develop asset-based social enterprises through revenue grants, technical assistance (legal, investment and planning advice) and feasibility analysis as well as support for new staff, working capital and prototyping new services and products. The support is not prescriptive but is designed as a package based on an audit of local needs, planning priorities, capacities and the long-term feasibility of the business. The project aimed to create a range of outcomes that included new business starts, 
strengthening turnover, jobs, taking people off welfare and into quality paid work, improving services and facilities and removing blight. In broad terms, EDT offered three levels of support and businesses could staircase through the development programme:

- Level one supports the creation of new asset-based social enterprises through their first three years of growth. Grant investments are generally below $£ 30,000$ and help groups get to the first stage of commercial viability.

- Level two aims to grow established, medium-sized firms in order to strengthen sustainability and long-term profitability and participants received larger grants in the $£ 30,000-£ 60,000$ range.

- Level three investments aim to consolidate larger social enterprises, especially by diversifying their income streams, enabling their entry into high growth tech sectors or to build capacity in business-to-business services. These organisations received investment support between $£ 60,000$ and $£ 100,000$.

By 2019, Grounds and Murtagh showed that EDT supported 22 social enterprises; created 51 jobs; put 661 participants through accredited training; leveraged an additional $£ 3.1 \mathrm{~m}$ investment into participating projects; and generated $£ 0.58 \mathrm{~m}$ in new sales ${ }^{1 x x i i i}$. Using audited accounts of organisations before and after the programme, the review also shows that every additional $£ 1$ EDT provided, increased end of term sales by $£ 0.50 \mathrm{p}$ and turnover by $£ 6.81^{\text {lxxiv }}$. Beneficiaries included large social enterprises, including ACT and smaller informal businesses such as Men's' Shed who aim to tackle loneliness among older men. Figure 1 sets out the peacebuilding effects of the programme and provides a better understanding of the different types of social enterprise activity supported by EDT. These include: 
1. Providing services for post-conflict transition;

2. Building cultural understanding, tolerance and mutual respect;

3. Supporting heritage and peace;

4. Promoting relationships with 'other' identities;

5. Interface management and shared space; and

6. Economic development and pathways out of poverty.

Figure 1 Peace outcomes and social economics

\begin{tabular}{|c|c|c|c|}
\hline Peace effect & Projects & Transformations & Outcomes \\
\hline $\begin{array}{l}\text { Services for post- } \\
\text { conflict transition }\end{array}$ & $\begin{array}{l}\text { TAMHI | Bridge of Hope } \\
\text { [Sante Health] }\end{array}$ & $\begin{array}{l}\text { Community based but commercial projects } \\
\text { that address trauma, the local effects of the } \\
\text { Troubles and post-conflict adjustment. }\end{array}$ & $\begin{array}{l}\text { Sustaining and } \\
\text { professionalising effective } \\
\text { trauma services }\end{array}$ \\
\hline $\begin{array}{l}\text { Expressing other } \\
\text { identities }\end{array}$ & $\begin{array}{l}\text { Men's Shed | Arts for All | } \\
\text { NI Hospice | Unitorah }\end{array}$ & $\begin{array}{l}\text { Giving space for other identities to find socio- } \\
\text { spatial expression including the isolated and } \\
\text { lonely, religions, arts and carers. }\end{array}$ & $\begin{array}{l}\text { Integrating marginal groups } \\
\text { and interests into the } \\
\text { community space }\end{array}$ \\
\hline $\begin{array}{l}\text { Progressive } \\
\text { heritage }\end{array}$ & $\begin{array}{l}\text { Clifton House | Carlisle } \\
\text { Memorial }\end{array}$ & $\begin{array}{l}\text { Developing the economic potential of assets } \\
\text { that offer an alternative heritage to green and } \\
\text { orange identity politics. }\end{array}$ & $\begin{array}{l}\text { Space for histories that } \\
\text { disrupt sectarian narratives } \\
\text { of the past }\end{array}$ \\
\hline $\begin{array}{l}\text { Cultural tolerance } \\
\text { and respect }\end{array}$ & $\begin{array}{l}\text { Rathfern | HUBB Centre | } \\
\text { McCracken Centre }\end{array}$ & $\begin{array}{l}\text { Transforming single identity projects to reach } \\
\text { new markets, supply chains and business-to- } \\
\text { business networks. }\end{array}$ & $\begin{array}{l}\text { Commercial inter- } \\
\text { dependence, unsettling } \\
\text { single-identity narratives }\end{array}$ \\
\hline $\begin{array}{l}\text { Interface } \\
\text { management }\end{array}$ & $\begin{array}{l}\text { ABC | Grace Women's } \\
\text { Centre | Ardoyne Youth }\end{array}$ & $\begin{array}{l}\text { Commercialisation of the interface. Restoring } \\
\text { use-value to places blighted by segregation, } \\
\text { contestation and fear. }\end{array}$ & $\begin{array}{l}\text { Physical development of } \\
\text { interfaces with services, } \\
\text { facilities and local finance }\end{array}$ \\
\hline $\begin{array}{l}\text { Pathways out of } \\
\text { exclusion }\end{array}$ & $\begin{array}{l}\text { North City | FABLAB | } \\
\text { Greenworks | Task Team | } \\
\text { Upright Housing }\end{array}$ & $\begin{array}{l}\text { Supporting new firms, intermediary labour } \\
\text { markets, locally viable jobs and facilities in } \\
\text { underserved communities. }\end{array}$ & $\begin{array}{l}\text { Addressing poverty and } \\
\text { segregation as an } \\
\text { interdependent challenge }\end{array}$ \\
\hline
\end{tabular}

These are not core aims of the programme, but rather, are outcomes of the collective and integrated work of the projects funded. To some extent, this is demand driven rather than deliberative, in that EDT works with established asset holding social enterprises, but it does suggest pathways to create multiple peace effects, shaped by the material exclusions that characterise the most divided communities. For example, services for post-conflict transition are delivered by a number of groups dealing with trauma, wellbeing and mental health but it shows that there are opportunities to sustain such interventions, in the absence of grant aid. As dealing with the past becomes a more intractable political issue, services still need to be 
delivered to people living with the legacies of violence. Training in counselling and building wraparound care to cope with high levels of suicide linked to the Troubles, shows how quality services can be maintained in post-conflict conditions, especially after international donors have left. The analysis also shows that social enterprises have enabled other identifications to form (around youth, gender and race) and opportunities for encounter that build on established points of contact. Here, there is a need to move beyond simplistic ideas of 'sharing' to see how such meaningful encounters create new resources, useful work and assets for the lonely and isolated, those at the end of their life, or who express their identities as women, young people and families.

The past, cultural heritage and identity have been carefully politicised, especially in north Belfast where place claiming is a constant performative and provocative act. Flags, graffiti and ritual parades remind the other about ownership and bolster paramilitaries as defenders of an always threatened and imagined territory. The Belfast Charitable Society project challenges these processes by creating a heritage centre (with related and profitable corporate catering and conference facilities) based on the history of radical 18thC Presbyterians involved in poor relief, social reform and early town planning in the 200-year-old Clifton House. The Society drew on the ideals of the American and French revolutions to form the United Irishmen, which involved dispossessed Protestants and Catholics in the 1798 rebellion against British rule. The tradition of a Presbyterian mercantile class articulating a radical republican cause is a history that does not fall into a neat sectarian binary but offers a progressive narrative about the complex relationship between poverty, social justice and identity that has always shaped the area. Nagle argues that these non-aligned cultural movements create an 'inward collective consciousness' that challenges sectarian formations and builds alliances with other identities, leading ultimately to attitudinal change: 
This non-sectarian memorywork is utilized to open up narratives regarding histories of intercommunal solidarity and community that have been elided and obscured by contemporary forms of ethnicized remembrance ${ }^{1 \mathrm{xxv}}$.

It would be wrong to assume that cultural projects are, or need to be, cross-community, but they should be tolerant, respectful and in this case profitable. Projects that serve their own spatial or identity communities have had to think through new modes of delivery that extend their catchment, supply chains and to trade with other places and community businesses in more practical ways. The Belfast Charitable Society successfully brought together 11 projects within a new North Belfast Heritage Cluster, which enabled each one to see their culture presented in relation to alternative sites, narratives and histories. They have not necessarily changed their identity, but are confronted with alternative narratives, commercial opportunities and potential business alliances, but always in relation to the other.

A set of projects more directly confronted the effects of the interface by removing a dead, derelict and dangerous space to create a use value for communities on either side of the peace line. The experience here shows that social enterprises, that work across places and identities, including gendered and youthified spaces, have the potential to repurpose the peace line in a way that provides local services and facilities. Grace Women's Centre is creating a new childcare facility facing into both communities on the peace line, but more importantly it creates jobs, opportunities for women to return to work and a waged economy in the context of welfare austerity. 
Finally, and most importantly, the social economy offers a pathway for local development that builds alternative economic trajectories embedded in the needs and capabilities of even the poorest neighbourhoods. A number of the larger scale level 3 investments focused on the Ashton Community Trust (ACT) and to some extent scale matters in achieving stronger economic and community relations effects. ACT started with a Community Share issue of 720 shares, at $£ 35$ per share as initial capital, to develop a small enterprise centre. This pump-prime funding gave the community a material stake in the organisation and showed commitment and self-confidence to resource further developments. Over time, the organisation built up resources, primarily from rental income, to develop a new, multi-purpose facility that provides childcare, community services and ground floor retail units. ACT currently employs 250 people, has a turnover of $£ 8 \mathrm{~m}$, assets worth $£ 3 \mathrm{~m}$, including 10 properties and an operating profit of $£ 1.2 \mathrm{~m}$ (in 2016-17).

Moreover, ACT creates significant local multiplier effects by generating jobs, services and assets tailored to the local labour market and structure of the neighbourhood economy. Every year, ACT invests $£ 6 \mathrm{~m}$ in salaries and supply chains and nearly two-thirds of salaries are spent within the area, with $64 \%$ in the top $20 \%$ socially deprived neighbourhoods in Northern Ireland $^{\text {lxxvi }}$. Suppliers are less proximate and of the $£ 3 \mathrm{~m}$ annual spend, most (56\%) goes out of the neighbourhood. However, nearly three-quarters (74\%) of all supplier spend is with other social enterprises, creating significant sectoral interdependencies ${ }^{\text {xxvii }}$. The multiplier effects and the economic investment by EDT is limited but calls for a new understanding of agency based on the control and ownership of (modest) circuits of production and consumption in divided communities. It is clearly difficult to make a causal connection between economic mobility and an end to violence. But, as Sen observed, it is in poverty that conditions of ethnic conflict are embedded and easily manipulated ${ }^{\text {lxxviii }}$. Providing expression for other identity 
formations and critically economic rights, are a significant part of the response to violence and how it survives after war.

\section{Conclusions}

Conflict after peace is persistent because the assemblage of violence is so well ingrained and embedded in the places where and when they have proved useful. The spatiality of violence and how to transform (if not end) it, requires a deeper understanding of these regimes and how they can be confronted or edged out in the poorest communities. The already shaky concept of Northern Ireland has not delivered for working class Catholics and nor has it for poor Protestant neighbourhoods either. Building inclusive citizenship, which is necessary for a post-conflict sense of political and economic rights has simply not materialised in the most disadvantaged communities. The rehabilitation of paramilitary structures to maintain the armed struggle or for criminal accumulation, underwrite logics of violence in the context of such poverty.

The implications of these processes for peacebuilding are threefold. First, it shows that the nature of conflict changes and the character of violence restructures in the context of wider political and especially economic processes. Logics of ethnic conflict can be pushed out, to some extent, by the benefits of socio-economic mobility. This does not, of course, mean that ethnicity, race and religion are removed as meaningful markers of identity, only that they are negotiable with an evident plasticity in which space (in this case at least) is an important site of peace-making. Second, the nature of space, its social reproduction and how struggles to assert economic or ethnic control, all require a deeper analysis of the modalities of placemaking. In short, how space is assembled by actors, policies, laws, resources and communities stress the need to understand the interplay between territory and extant infrastructures of war, the assertion of neoliberal economics and the role of the state in conditions of peace. There are 
inherent dangers in privileging space and ethnic binaries, which in turn, highlights the multiple, overlapping and contradictory processes that can re-territorialize or de-territorialize violence in post-war cities. The spatial turn in peacebuilding and transitional uncertainty, draws attention to these everyday realities of contested places and their fragility after violence has ended. Here, the paper argues that we need to move beyond space as an abstract concept or empirical container to understand how specific socio-political, ethnic and economic regimes shape the post-war city. Assemblage thinking is useful because it does not treat space simply as the geographic outworking of peace negotiations or intergroup compromise. Rather, it reveals the place-making processes that are institutional, global and local in which the city becomes spatially differentiated as ethnic regimes survive alongside modernising economics. The problem in Belfast is that peace lines are read as a spatial relic of unresolved and unforgiven violence and become essentialized in case studies, attitudinal surveys and an emphasis on personal encounter. And, to some extent they are, but by tracing the structures, actors, networks, resources and practices that shape the differential fortunes of violent and peaceful places, space becomes a more active site of political mobilisation and inclusive economic practice.

Third, assemblage thinking then pays attention to the possibilities to disassemble dominant regimes and assert alternative ways of working. Alternative economics that centre on the most marginal places and how to recycle limited resources within and between divided communities, is an arena of experimentation and potential. The local, even deeply divided localities have changed because communities can realise jobs, incomes, services and the peace that comes with a recognition of the commons over sectarianized space. The neighbourhood cannot be privileged in these formulations and there is a distinct 'local trap' in micro economic responses. There is clearly a need to scale these processes in extra-local alignments that involve business 
networks, supply chains, intermediaries such as EDT, finance and regulatory incentives, which might offer a different trajectory for the post-conflict city. This is the very material of antiviolence work under conditions of peace. The fuzzy governance of review panels, guidance and monitoring reports focus on only part of the place-violence nexus. So too does community relations interventions that encourage a single-identity construct of conflict. Space is reproduced by political, identarian but crucially, economic structures that need to be brought into relation in order to address violence and its utility to those left out of the peace dividend. 


\section{References}

Björkdahl, Annika and Stephanie Kappler. Peacebuilding and Spatial Transformation: Peace, Space and Place. London: Routledge, 2017.

Boland, Philip, Linda Fox-Rogers, Stephen McKay and Brendan Murtagh. "Illegal geographies and spatial planning: developing a dialogue on drugs." Territory, Politics, Governance, early release online (2018): 1-27. doi. 10.1080/21622671.2018.1503092.

Cadwallader, Anne. Lethal Allies: British Collusion in Ireland. Cork: Mercier Press, 2013.

Castells, Manuel. The Rise of the Network Society (2nd Edition). New York: Blackwell Publishing, 2000.

Chatterjee, Ipsita. "Beyond the factory: Struggling with class and class struggle in the postindustrial context." Capital and Class 40, no. 2 (2016): 263-281. doi.10.1177/0309816815604630.

Coulter, Colin and Peter Shirlow. 'From the 'Long War' to the 'Long Peace': An introduction to the special edition." Capital and Class 43, no. 3 (2019): 3-21. doi. $10.1177 / 0309816818818084$.

Dwyer, Claire. "Expanding DDR: The transformative role of former prisoners in communitybased reintegration in Northern Ireland.” International Journal of Transitional Justice 6, no. 2 (2012): 274-295. doi. 10.1093/ijtj/ijs014. 
Gallaher, Carolyn. After the Peace: Loyalist Paramilitaries in Post-accord Northern Ireland. New York: Cornell University Press, 2007.

Grounds, Andrew and Brendan Murtagh. Building Social Economies: The Impact of the EDT Programme. Belfast: Queen's University Belfast, 2019.

Gusic, Ivan. "The relational spatiality of the postwar condition: A study of the city of Mitrovica." Political Geography 71 (2019): 47-55. doi. 10.1016/j.polgeo.2019.02.009.

Hayward, Katy. "The pivotal position of the Irish border in the UK's withdrawal from the European Union." Space and Polity 22, no. 2 (2018): 238-254. doi. 10.1080/13562576.2018.1505491.

Hoey, Patrick. "Dissident and dissenting republicanism: From the Good Friday/Belfast Agreement to Brexit." Capital and Class 43, no.1 (2019): 73-87. doi. 0309816818818088.

Jamieson, Ruth and Kieran McEvoy. "State crime by proxy and juridical othering." British Journal of Criminology 45, no. 4 (2005): 504-527. doi. 10.1093/bjc/azi035.

Joyce, Carmel and Orla Lynch. “'Doing Peace': The role of ex-political prisoners in violence prevention initiatives in Northern Ireland." Studies in Conflict and Terrorism 40, no. 12 (2017): 1072-1090. doi.10.1080/1057610X.2016.1253990. 
Khoury, Theodore and Ajnesh Prasad. "Entrepreneurship amid concurrent institutional constraints in less developed countries.” Business and Society 55, no. 7 (2016): 934-969. doi. $10.1177 / 0007650314567641$.

Latour, Bruno. Reassembling the Social: An Introduction to Actor-Network-Theory. Oxford: Oxford University Press, 2005.

Lefebvre, Henri. "Right to the city." In Writings on Cities, edited by Eleonore Kofman and Elizabeth Lebas, 61-181. Oxford: Blackwell, 1996.

McCall, Cathal. "Brexit, bordering and bodies on the island of Ireland." Ethnopolitics 17, no. 3 (2018): 292-305. doi. 10.1080/17449057.2018.1472425.

McEvoy, Kieran and Peter Shirlow. "Re-imagining DDR: Ex-combatants, leadership and moral agency in conflict transformation." Theoretical Criminology 13, no. 1 (2009): 31-59. doi. $10.1177 / 1362480608100172$.

McFarlane, Colin. “Assemblage and critical urbanism.” City 15, no. 2 (2011): 204-224. doi. 10.1080/13604813.2011.568715.

McGlinchey, Marisa. Unfinished Business: The Politics of 'Dissident' Irish Republicanism. Manchester: Manchester University Press, 2019. 
McGuirk, Pauline, Kathy Mee and Kristan Ruming. “Assembling urban regeneration? Resourcing critical generative accounts of urban regeneration through assemblage." Geography Compass 10, no. 3 (2016): 128-141. doi. 10.1111/gec3.12255.

McKeever, Grainne. "Citizenship and social exclusion: The re-integration of political exprisoners in Northern Ireland." The British Journal of Criminology 47, no. 3 (2006): 423-438. doi. 10.1093/bjc/azl070.

McKittrick, David, Seamus Kelters, Brian Feeney and Chris Thornton. Lost Lives: The Stories of the Men, Women and Children Who Died as a Result of the Northern Ireland Troubles. London: Random House, 2001.

Morgan, Kevin. "Collective entrepreneurship: The Basque model of innovation.” European Planning Studies 24, no. 8 (2016): 1544-1560. doi. 10.1080/09654313.2016.1151483.

Murtagh, Brendan. "Contested space, peacebuilding and the post-conflict city.” Parliamentary Affairs 71, no. 2 (2017): 438-460. doi. 10.1093/pa/gsx031.

Murtagh, Brendan. Social Economics and the Solidarity City. London: Routledge, 2019.

Nagle, John. "Intervention: grassroots organizing and mobilization." Space and Polity, early release online (2019): 1-5. doi. 10.1080/13562576.2019.1588720. 
Nussio, Enzo. “Ex-combatants and violence in Colombia: are yesterday's villains today’s principal threat?" Third World Thematics: A TWQ Journal 3, no. 1 (2018): 135-152. doi. $10.1080 / 23802014.2018 .1396911$.

O’Brennan, John. "Requiem for a shared interdependent past: Brexit and the deterioration in UK-Irish relations.” Capital and Class, 42 no. 1 (2019): 157-171. doi. 0309816818818315.

O'Leary, Brendan and John McGarry. The Politics of Antagonism: Understanding Northern Ireland. London: Bloomsbury Publishing, 2016.

Police Service of Northern Ireland (PSNI). 2018/19 Security Statistics - Monthly Update to 31 January 2019. Belfast: PSNI, 2019.

Purcell, Mark. "Possible worlds: Henri Lefebvre and the right to the city." Journal of Urban Affairs 36, no. 1 (2014): 141-154. doi. 10.1111/juaf.12034.

Satgar, Vishwas. "The solidarity economy alternative in South Africa." In The Solidarity Economy Alternative; Emerging Theory and Practice, edited by Vishwas Satgar, 199-226. Pietermaritzburg: University of KwaZulu-Natal Press, 2014.

Sen, Amartya. Identity and Violence: The Illusion of Destiny. Delhi: Penguin Books, 2007.

Shirlow, Peter. "Mythic rights and conflict-related prisoner 're-integration'." Capital and Class 43, no.1 (2019): 39-22. doi. 0309816818818088. 
Steenkamp, Christina. "In the shadows of war and peace: making sense of violence after peace accords." Conflict, Security and Development 11, no. 3 (2011): 357-383. doi. $10.1080 / 14678802.2011 .593813$.

Tomlinson, Michael. "Risking peace in the 'war against the poor'? Social exclusion and the legacies of the Northern Ireland conflict." Critical Social Policy 36, no. 1 (2016): 104-123. doi. $10.1177 / 0261018315609047$

Unwin, Tim. "A waste of space? Towards a critique of the social production of space" Transactions of the Institute of British Geographers 25, no. 1 (2000): 11-29. doi. 10.1111/j.0020-2754.2000.00011.x.

Venugopal, Rajesh. "Neoliberalism as concept.” Economy and Society 44, no. 2 (2015): 165187. doi. 10.1080/03085147.2015.1013356.

Vorrath, Judith. "What drives post-war crime? Evidence from illicit economies in Liberia and Sierra Leone." Third World Thematics: A TWQ Journal 3, no. 1 (2018): 28-45. doi. 10.1080/23802014.2018.1408426.

World Bank. Social Innovation for Peacebuilding in Colombia. Washington: World Bank, 2017.

Yiftachel Oren and Asad Ghanem. "Understanding 'ethnocratic' regimes: The politics of seizing contested territories." Political Geography 23, no. 6 (2004): 647-676. doi. 10.1016/j.polgeo.2004.04.003. 


\section{Notes}

${ }^{\mathrm{i}}$ Steenkamp, Shadows of War and Peace.

ii Ibid., 359.

iii Ibid., 360.

iv McFarlane, Assemblage and Critical Urbanism.

v Yiftachel and Ghanem, Understanding 'Ethnocratic' Regimes.

${ }^{v i}$ Murtagh, Social Economics.

vii Björkdahl and Kappler, Peacebuilding and Spatial Transformation.

viii Ibid., 14.

${ }^{i x}$ Gusic, Relational Spatiality.

${ }^{x}$ Unwin, Waste of Space, 12.

${ }^{x i}$ Purcell, Possible Worlds.

xii Unwin, Waste of Space, 22.

xiii Castells, Network Society.

xiv Purcell, Possible Worlds.

${ }^{\mathrm{xv}}$ Unwin, Waste of Space.

${ }^{x v i}$ Murtagh, Contested Space.

xvii Lefebvre, Right to the City,173-74.

xviii Steenkamp, Shadows of War and Peace, 359.

xix Ibid., 360.

${ }^{\mathrm{xx}}$ Chatterjee, Beyond the Factory.

xxi Yiftachel and Ghanem, Understanding 'Ethnocratic' Regimes.

xxii Venugopal, Neoliberalism as Concept.

xxiii Latour, Reassembling the Social.

${ }^{x x i v}$ McFarlane, Assemblage and Critical Urbanism, 209.

${ }^{x x v}$ McGuirk, et al. Assembling Urban Regeneration.

xxvi O'Leary and McGarry, Politics of Antagonism.

xxvii McKittrick et al., Lost Lives.

xxviii Murtagh, Contested Space.

xxix Nagle, Grassroots Organisations.

${ }^{x x x}$ O'Leary and McGarry, Politics of Antagonism.

xxxi O'Brennan, Shared Interdependent Past.

xxxii Hayward, Irish Border.

xxxiii Hoey, Dissident and Dissenting Republicanism.

xxxiv Steenkamp, Shadows of War and Peace.

xxxv Vorrath, What Drives Post-war Crime.

xxxvi Gallaher, After the Peace.

xxxvii McGlinchey, Unfinished Business.

xxxviii O'Brennan, Requiem for a Past.

xxxix Cadwallader, Lethal Allies.

xl Jamieson and McEvoy, State Crime by Proxy.

xli Tomlinson, Risking Peace.

xlii McGlinchey, Unfinished Business.

xliii Based on PSNI, table $1 *$ No data between 1973-1981 inclusive.

xliv Dwyer, Expanding DDR.

xlv Shirlow, Mythic Rights.

xlvi Ibid., p.7.

xlvii Ibid. 
xlviii Ibid., p.7.

${ }^{x l i x}$ Nussio, Ex-combatants and Violence.

${ }^{1}$ McCall, Brexit, Bordering and Bodies.

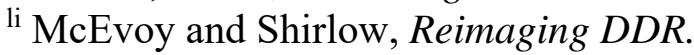

lii Joyce and Lynch, Doing Peace.

liii Ibid., 1081.

liv Ibid., 1084.

${ }^{\text {lv }}$ McEvoy and Shirlow, Reimaging DDR.

${ }^{\text {lvi }}$ Coulter and Shirlow, From the Long War.

lvii McKeever, Citizenship and Social Exclusion.

lviii Cadwallader, Lethal Allies.

lix Joyce and Lynch, Doing Peace.

${ }^{1 x}$ Boland et al., Illegal Geographies.

${ }^{1 x i}$ Hoey, Dissident and Dissenting Republicanism.

lxii Ibid., 11.

lxiii O'Brennan, Requiem for a Past.

lxiv Björkdahl and Kappler, Peacebuilding and Spatial Transformation.

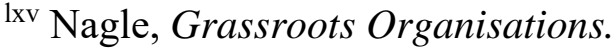

lxvi World Bank, Social Innovation for Peacebuilding.

lxvii Ibid., 11.

lxviii Khoury and Prasad, Entrepreneurship Amid Constraints.

${ }^{1 x i x}$ Chatterjee, Beyond the Factory.

1xx Satgar, The Solidarity Economy.

1xxi Morgan, Collective Entrepreneurship.

lxxii Murtagh, Contested Space.

1xxiii Grounds and Murtagh, Building Social Economies.

1xxiv Ibid., 22.

1xxv Nagle, Grassroots Organisations, 3.

lxxvi Grounds and Murtagh, Building Social Economies.

1xxvii Ibid., 25.

lxxviii Sen, Identity and Violence. 